\title{
Society and Culture in Early Modern France
}

\section{Eight Essays by Natalie Zemon Davis}

These essays, three previously unpublished, explore the competing claims of innovation and tradition in I6th-century France. The result is a wide-ranging new view of men and women (artisans, tradesmen, the poor) who, because they left little or nothing in writing, have been hitherto neglected by scholars. The papers discuss such topics as the social sources, composition, and consequences of Calvinism; the function of festivals of status and sex role reversal (carnivals etc.); popular violence; youth groups; journeymen's societies; male and female literacy rates; and the relation between oral, popular, and learned culture. March. About \$I2.50

\section{The Chinese City Between Two Worlds}

Edited by Mark Elvin \& $G$. William Skinner. Important though the countryside was as the basis of Mao's rise to power, the roots of the Chinese revolution were urban and can only be understood in terms of their urban setting. Twelve scholars trace the role of cities in Chinese history from I842-r949, emphasizing these urban roots. Among the topics covered are the treaty ports, the growth of financial institutions, revolutionary mobilization, warlord control, social reform, administrative transformation, religious change, and patterns of migration. Studies in Chinese Society. \$18.75

\section{Stanford University Press}




\section{THE WORLD TODAY}

STUDENTS OF CURRENT AFFAIRS, to be well informed, need the facts. In THE WORLD TODAY, the monthly journal of the Royal Institute of International Affairs, experts bring to the general reader up-to-date and reliable information on world affairs.

Authoritative and objective, THE WORLD TODAY deals primarily with international problems but also includes articles on internal political and economic conditions in individual countries or regions, written by authors with first-hand knowledge. Short comment in 'Notes of the Month' puts current developments in perspective and provides a background to events of international significance.

\section{MONTHLY}

Price 40 p per copy; $£ 4.75$ per year post free (in USA and Canada $\$ 15$ by accelerated surface post)

Published under the auspices of the

ROYAL INSTITUTE OF INTERNATIONAL AFFAIRS, LONDON

by the Oxford University Press

Press Road, Neasden, London,

NWIO ODD
Backward Toward Revolution

The Chinese Revolutionary Party

Edward Friedman

Focusing on the years just prior to the founding of China's Communist Party, Mr. Friedman studies the revolutionary efforts of China's rural rebels and radical intellectuals. Asking what fused the explosive energies of these people, he finds the answer not in organizational secrets but in the personal, familial and religious crises of the people, in the values and beliefs of the revolutionaries themselves.

257 pages $\$ 12.75$

\section{Byzantium and Bulgaria}

A Comparative Study Across the Early Medieval Frontier Robert Browning

Concentrating on the crucial period of the 9th and 10th centuries, Mr. Browning studies the establishment of the Bulgarian state in the northern half of the Balkan peninsula, its relations with the East Roman Empire, and the development of institutions and way of life. He finds that Bulgaria and Byzantium were not merely comparable, but were contiguous and were in continuous political, military, religious, commercial and cultural contact with one another. 312 pages $\$ 10.95$

At your bookseller

UNIVERSITY OF CALIFORNIA PRESS

Berkeley - Los Angeles - New York 
Appearing in the Industrial and Labor Relations Review:

\section{EUROPEAN LABOR AND POLITICS:}

\section{A SYMPOSIUM}

Edited by John P. Windmuller

\section{OCTOBER 1974}

The British Labour Party and the Trade Unions: Crisis and Compact, by Lewis Minkin

Trade Unions and Political Parties in the Federal Republic of Germany, by Richard J. Willey

In Search of New Relationships: Parties, Unions, and Salaried Employees' Associations in Sweden, by Nils Elvander

Strategic Opportunities and Limitations: The Norwegian Labor Party and the Trade Unions, by Penny Gill Martin

\section{JANUARY 1975}

Labor and Politics in a Divided Movement: The Italian Case, by Peter Weitz

Trade Unions and Political Parties in France: Some Recent Trends, by Jean-Daniel Reynaud

Labor Unions and Political Parties in Belgium, by Val R. Lorwin

Current Problems of Trade Union-Party Relations in Switzerland: Reorientation Versus Inertia, by Jürg K. Siegenthaler

Order from: Industrial and Labor Relations Review (a quarterly), Cornell University, Ithaca, N.Y. 14853

Annual subscription: $\$ 10$ (domestic), $\$ 11$ (foreign), $\$ 5$ (student)

Single copies: $\$ 2.75$ (domestic), $\$ 3.00$ (foreign) 


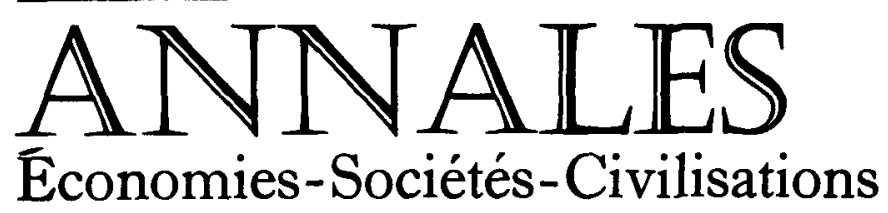

Revue bimestrielle, fondée en 1929 par Lucien FEBVRE et Marc BLOCH

Comité de Direction: Fernand BRAUDEL, Marc FERRO, Georges FRIEDMANN, Jacques LE GOFF, Emmanuel LE ROY LADURIE, Charles MORAZE

Secrétaires du Comité: Paul LEUILLIOT, Marianne MAHN-LOT

Secrétaire de la Rédaction: André BURGUIÊRE

29e ANNEE-No. 5

SEPTEMBRE-OCTOBRE 1974

LES DOMAINES DE L'HISTOIRE

Charles TILLY et Lynn LEES, Le peuple de Juin 1848

Jean-Louis ROBERT et Michel CHAVANCE, L'évolution de la syndicalisation en France de 1914 à 192 I

COMPTES RENDUS: D'une Révolution à l'autre

Jean BOUVIER, Réflexion à propos d'une thèse sur l'investissement international avant I9I4 (Note critique)

NOTES BREVES: Espaces, problèmes économiques et populations

INTER-SCIENCES

Dominique SCHNAPPER, Centralisme et fédéralisme culturels: les émigrés italiens en France et aux Etats-Unis

André NOUSCHI, Villes du monde méditerranéen (Note critique) COMPTES RENDUS: Vie scientifique

HERESIE, RELIGION ET MENTALITESS

Shulameth SHAHAR, Le catharisme et le début de la cabbale

John MUNDY, Noblesse et hérésie. Une famille cathare: les Maurand NOTES BREVES: Vie religieuse

Huguette TAVIANI, Naissance d'une hérésie en Italie du Nord au XIe siècle

Marie-Dominique CHENU, Civilisation urbaine et théologie. L'École de SaintVictor au XIIe siècle

Jean SÉGUY, Du cultuel au culturel (Note critique)

Paul VEYNE, Les Juifs, le judaïsme et le monde moderne (Note critique)

Rédaction: 54, Boulevard Raspail, 75006-Paris

Administration: Librairie Armand COLIN, I03, Boulevard Saint Michel, 75005

Paris

Comptes Chèques Postaux: PARIS, $\mathrm{N}^{\circ} 2$ I $335^{-25}$

Abonnements: France et Pays de la Communauté: 90 F. (Etudiant France:

$60 \mathrm{~F}$.) Etranger: $100 \mathrm{~F}$.

Le numéro: $18 \mathrm{~F}$.-Numéros spéciaux: $36 \mathrm{~F}$. 


\section{SURVEY}

\section{A Journal of East and West Studies}

\section{Volume 20 No. 4 (93)}

\section{Autumn 1974}

\section{INTERNATIONAL TERRORISM}

Roberta Wohlstetter

\section{EAST-WEST RELATIONS}

Robert Byrnes

Robert Legroid

\section{THE SOVIET SCENE TODAY}

Scientists as Entrepreneurs

The CPSU: A Report from Inside

Expulsion of Western Correspondents

\section{NEW TRENDS IN RUMANIA}

Kenneth Jowitt

\section{VIEWS AND REVIEWS}

The Gulag Archipelago: Volume II

Kontinent

Agnes Smedley in China

\section{Annual subscription $£_{4}$ or US $\$ 10$ \\ Student rates $£_{2}$ or US $\$ 5$ \\ Single copies: $f_{\text {I }}$ or US $\$ 2.50$}

Editorial Office: Ilford House, 133 Oxford Street, London W I R ITD (Tel. (O1) 734 0592)

Subscription Office: Oxford University Press, Press Road, Neasden, London NW 10 oDD 


\section{Announcing an important new series}

\section{PAST AND PRESENT SUPPLEMENTS}

Past and Present has always been most anxious to be very flexible over the length of its articles, and it has published some articles far longer than one normally finds in journals. Unfortunately the pressures on our space are now so great that it is no longer possible for us, save in. most exceptional circumstances, to publish such long articles in the journal itself. But we fully recognize the importance of continuing to provide authors with an outlet for long studies of between about 40 and 100 pages of print (18-45,000 words, including footnotes), and indeed to publish more of these than we have been able to in the past. We have therefore decided to launch a series of Supplements, which will be in the same format as the journal. The first two Supplements are:

I. J. R. MaddicotT, The English Peasantry and the demands of the Crown 1294-134I. 73 pp. PRICE 95P. (\$3).

2. R. J.W. Evans, The Wechel Presses: Humanism and Calvinism in Central Europe 1572-1627. 75 pp. PRICE 95p. (\$3).

Libraries and other institutions are particularly urged to place Standing Orders for the series of Supplements.

Copies are obtainable from:

The Business Manager, Past and Present, P. O. Box 28, Oxford OX2 $7 \mathrm{BN}$, England.

Please await receipt of invoice before sending any remittance.

We invite authors to submit studies of between about 40 and 100 pages of print (18-45,000 words, including footnotes). These should be sent (two copies) to:

The Editor, Past and Present, Corpus Christi College, Oxford OXr 4JF. 


\section{The Eastern Anthropologist}

Volume 27 No. $4-1974$

Original papers

N.V.KAMESWARA Impact of Drought on the social system of a RAO

Telangana Village

K. N.THUSU \&

BAGESHWAR

SINGH

ROOP SINGH

MARY GHATTER-

JEE

K.S.MATHUR

Shorter note

Kinship term of the Parji-Kolami tribes

Labels and tribal identity in southern Rajasthan

Kinship in an urban low caste locality

Society in India

The Telugu scavengers of Kalmunai : a sociolinguistic study

Communications

from T.N. Madan, Delhi

G. Ansari, Kuwait

N. Hasnain, Lucknow

President, IUAES \& ICAES

Book Reviews

From 1975

Annual subscription

in India

Rs. 40.00 Rs. 60.00

in U.K.

$£ 3.50$

$£ 5.00$

elsewhere in the world US $\$ 9.00$ US $\$ 14.00$

Published by

Ethnographic \& Folk Culture Society, U.P., P. O. Box No. 209,

Lucknow (India)

Editorial address

C/O Department of Anthropology University of Lucknow, Lucknow (India) 
Comparative Studies in Society and History is a forum for presentation and discussion of new research into problems of change and stability that recur in human societies through time or in the contemporary world. It sets up a working alliance between specialists in all branches of the social sciences and humanities. Debate and review articles bring the general reader in touch with current findings and issues.

\section{NOTES FOR CONTRIBUTORS}

Contributions may be descriptive, analytical or theoretical. Any article not in itself comparative may be accepted if it lends itself to comment that will place it in comparative perspective. Correspondence with the editors prior to the submission of articles will help to enable them to obtain such comment or a companion study. Emphasis in comparative studies may be either on similarities or, if these are significant enough and call for some recasting of generalisations, on differences. All contributions and editorial correspondence should be sent to the Editors, Comparative Studies in Society and History, Department of History, University of Michigan, Ann Arbor, Michigan 48104.

Two copies of each contribution, preferably accompanied by a stamped, addressed envelope, should be submitted. Both text and footnotes should be clearly typed with double spacing and wide margins; footnotes should appear on separate pages at the end of the article. Illustrations may be included by arrangement with the editors.

Contributors will receive 50 offprints bound in the journal covers. Any additional offprints must be ordered on receipt of the first proof.

ISI Tear Service, 325 Chestnut Street, Philadelphia, Pennsylvania 19106, U.S.A is authorized to supply copies of separate articles for private use only.

Claims for missing issues will be considered only if made immediately upon receipt of the subsequent issue. 


\section{COMPARATIVE STUDIES IN SOCIETY AND HISTORY}

Editorial Foreword

Social Stratification

Howard Newby The Deferential Dialectic

DAvid LANE Ethnic and Class Stratification in Soviet Kazak-hastan 1917-1939

\section{Traditional Beliefs and Modernizing Change}

ShahroUgh AKHA Vi Egypt's Socialism and Marxist Thought: Some Preliminary Observation on Social Theory and Metaphysics

Richard F. Gombrich Buddhist Karma and Social Control

Christel LANe Socio-PoliticalAccommodation and Religious Decline: The Case of the Molokan Sect in Soviet Society

\section{Debate on Modernization}

Edward Hansen, Jane Schneider and Peter SCHNEIDER From Autonomous Development to Dependent Modernization: The Catalan Case Revisited: A Reply to Pi-Sunyer

ORIOL PI-SUNYER Of Corporate Groups and Vanishing Development: A Reply to Hansen, Schneider and Schneider

L. E. ShIner Tradition/Modernity: An Ideal Type Gone Astray

HARRY A. MISKIMIN The Quality of Quantitative Work: Review Article

(C) Society for the Comparative Study of Society and History, 1975

Cambridge University Press

Bentley House, 200 Euston Road, London NW1 2DB

American Branch: 32 East 57th Street, New York, N.Y. 10022

$£ 3.00$ net; US $\$ 9.00$ in U.S.A. and Canada

1975 subscription price $£ 9.00$ (US $\$ 27.00$ in U.S.A. and Canada) for institutions; $£ 5.50$ (US $\$ 14.00$ ) for individuals 